\title{
Neph1 Is Reduced in Primary Focal Segmental Glomerulosclerosis, Minimal Change Nephrotic Syndrome, and Corresponding Experimental Animal Models of Adriamycin-Induced Nephropathy and Puromycin Aminonucleoside Nephrosis
}

\author{
Jenny Hulkko a Jaakko Patrakkac ${ }^{c}$ Mark Lal ${ }^{\mathrm{b}}$ Karl Tryggvason ${ }^{\mathrm{b}}$ \\ Kjell Hultenbyc Annika Wernerson ${ }^{\mathrm{c}}$ \\ Departments of a Clinical Science, Intervention and Technology, ${ }^{b}$ Medical Biochemistry and \\ Biophysics and ' Laboratory Medicine, Karolinska Institutet, Stockholm, Sweden
}

Key Words

Neph1 · Focal segmental glomerulosclerosis - Minimal change nephrotic syndrome ·

Adriamycin-induced nephropathy · Puromycin aminonucleoside nephrosis

\section{Abstract}

Background/Aims: The transmembrane proteins Neph1 and nephrin form a complex in the slit diaphragm (SD) of podocytes. As recent studies indicate an involvement of this complex in the polymerization of the actin cytoskeleton and proteinuria, we wanted to study the subcellular localization of Neph1 in the normal human kidney and its expression in focal segmental glomerulosclerosis (FSGS), minimal change nephrotic syndrome (MCNS), and the corresponding experimental models of Adriamycin-induced nephropathy (ADR) and puromycin aminonucleoside nephrosis (PAN). All these disorders are characterized by substantial foot process effacement (FPE) and proteinuria. Materials and Methods: Kidney biopsies from patients with primary FSGS (perihilar type) and MCNS were compared to normal renal tissue. Mouse and rat kidney cortices from days 7 and 14 after Adriamycin injection and days 2 and 4 after puromycin aminonucleoside injection, respectively, were compared to control mouse and rat kidney. Polyclonal antibodies against Neph1 and nephrin were used for immunoelectron microscopy, and semiquantification was performed. Results: We localized Neph1 mainly to, and in close proximity to, the SD. Double staining of Neph1 and nephrin showed the proteins to be in close connection in the SD. The total amount of Neph1 in the podocytes was significantly reduced in FSGS, MCNS, ADR, and PAN. The reduction of Neph1 was also seen in areas with and without FPE. Nephrin was reduced in MCNS and PAN but unchanged in FSGS. Conclusion: With nephrin (but not Neph1) unchanged in FSGS, there might be a disruption of the complex and an involvement of Neph1 in its pathogenesis. 


\section{Introduction}

The outer layer of the glomerular filtration barrier in the capillaries consists of terminally differentiated epithelial cells, namely podocytes. The podocytes have foot-like processes that arise from their cell bodies and cover the underlying glomerular basement membrane (GBM). The adjacent foot processes are connected via extracellular junctions, that is, slit diaphragms (SD). SD appear to have a critical role in the filtration barrier and also seem to be involved in maintaining the structural shape of the podocytes through dynamic signaling pathways. It is now commonly believed that injuries to the glomerulus lead to effacement of the podocyte foot processes and a replacement of the SD by tight junctions [1,2].

The first protein identified in the SD was nephrin [3] in 1998. Since then, numerous proteins have followed, for example, Neph1 [4], Fat1, and Fat2. Proteins such as ZO-1, podocin, CD2AP, Nck, and Grb2 are thought to be links between proteins of the SD and the actin cytoskeleton. Recent studies suggest that these proteins participate in the signaling events that maintain the structure and function of podocytes [5, 6].

Studies of glomerular diseases characterized by proteinuria and foot process effacement (FPE) have demonstrated alterations in the expression and localization of the SD proteins nephrin [7], podocin, and CD2AP, suggesting that molecular alteration of the SD contributes to the development of proteinuria.

Neph1, a transmembrane protein, member of the immunoglobulin superfamily and structurally similar to nephrin, was identified in mouse kidneys and located to the podocytes by Donoviel et al. [4] in 2001. Neph1 interacts with nephrin and with their cytoplasmic domains in the SD [8,9], where they form a multifunctional receptor complex. Garg et al. [10] showed that the nephrin-Neph1 complex transduces phosphorylation-mediated signals that induce actin polymerization in the podocytes.

Donoviel et al. [4] discovered that knockout in Neph1 (-/-) mice results in a podocyte effacement phenotype with proteinuria and early postnatal death. Knockdowns in zebra fish result in loss of SD and proteinuria [11], and Otaki et al. [12] showed a dissociation of Neph1 from nephrin in the initiation phase of Adriamycin-induced nephropathy (ADR). This prompted us to investigate and semiquantify the expression of Neph1 in human glomerular diseases with substantial FPE - focal segmental glomerulosclerosis (FSGS), minimal change nephropathy (MCNS), and the corresponding experimental models of ADR and puromycin aminonucleoside nephrosis (PAN) - and to compare it to that of nephrin in order to study the role of the complex in these diseases.

\section{Materials}

\section{Normal Human Renal Tissue}

This material has previously been described [13]. Polyclonal antibodies against Neph1 and nephrin were produced as described in Ruotsalainen et al. [14].

\section{Patients}

Patients who fulfilled the criteria for FSGS and MCNS clinically and histopathologically were chosen for the study. Classification of FSGS was performed according to the Columbia system $[15,16]$. All clinical data, including treatment and proteinuria, are presented in table 1.

Animals

Rats. The PAN study has previously been described [17]. 
Table 1. Clinical data on the patients included in the study

\begin{tabular}{llll}
\hline Patient & Age/sex & Proteinuria & Treatment \\
\hline Control 1 & - & - & - \\
Control 2 & $48 / \mathrm{F}$ & - & - \\
Control 3 & $57 / \mathrm{F}$ & - & - \\
Control 4 & n.a. & - & - \\
Control 5 & $58 / \mathrm{M}$ & - & - \\
\hline FSGS perihilar case 1 & $3 / \mathrm{M}$ & $1 \mathrm{~g} / 24 \mathrm{~h}$ & steroids, 6 months \\
FSGS perihilar case 2 & $39 / \mathrm{M}$ & $1.4 \mathrm{~g} / 24 \mathrm{~h}$ & none \\
FSGS perihilar case 3 & $32 / \mathrm{F}$ & $8 \mathrm{~g} / 24 \mathrm{~h}$ & ACE inhibitor \\
FSGS perihilar case 4 & $31 / \mathrm{F}$ & $1.5 \mathrm{~g} / 24 \mathrm{~h}$ & none \\
FSGS perihilar case 5 & $5 / \mathrm{M}$ & $1.7 \mathrm{~g} / 24 \mathrm{~h}$ & steroids \\
\hline MCNS case 1 & $9 / \mathrm{M}$ & $4.5 \mathrm{~g} / 24 \mathrm{~h}$ & none \\
MCNS case 2 & $61 / \mathrm{M}$ & $27 \mathrm{~g} / 24 \mathrm{~h}$ & none \\
MCNS case 3 & $30 / \mathrm{M}$ & $9 \mathrm{~g} / 24 \mathrm{~h}$ & none \\
MCNS case 4 & $13 / \mathrm{M}$ & $12.0 \mathrm{mg} / \mathrm{mmol}$ & steroids \\
MCNS case 5 & $11 / \mathrm{M}$ & $16.3 \mathrm{mg} / \mathrm{mmol}$ & steroids \\
MCNS case 6 & $60 / \mathrm{M}$ & $303.3 \mathrm{mg} / \mathrm{mmol}^{2}$ & none \\
\hline
\end{tabular}

Age is given in years. ${ }^{\mathrm{a}}$ Urine albumin/creatinine.

Mice. Six-week-old BALB/c mice, 16-20 g, were obtained from Charles River Laboratories (L'Arbresle, France). All experiments were conducted according to Swedish animal research regulations and approved by the local board of ethics.

\section{Methods}

Puromycin Aminonucleoside Nephrosis

The method has previously been described [17].

Adriamycin-Induced Nephropathy

The method has been described elsewhere [18].

\section{Urine and Blood Analysis of ADR Mice}

Spot urine was collected prior to Adriamycin injection (controls) and at days 7 and 14 after Adriamycin injection. Albuminuria was determined by analyzing protein in $1 \mu \mathrm{l}$ of urine by sodium dodecyl sulfate polyacrylamide gel electrophoresis and staining with PageBlue (Fermentas, St. Leon-Rot, Germany) as well as by a mouse albumin enzyme-linked immunosorbent assay (Exocell, Philadelphia, Pa., USA). Albuminuria was measured on gel.

\section{Immunoelectron Microscopy}

Tissue preparation has been described elsewhere [7]. Polyclonal antibodies against Neph1 and nephrin were both used at a concentration of 1:50. In the double staining of Neph1 and nephrin, secondary antibodies were conjugated with 10- and 5-nm gold particles, respectively. Section examination was conducted as previously described [13]. 

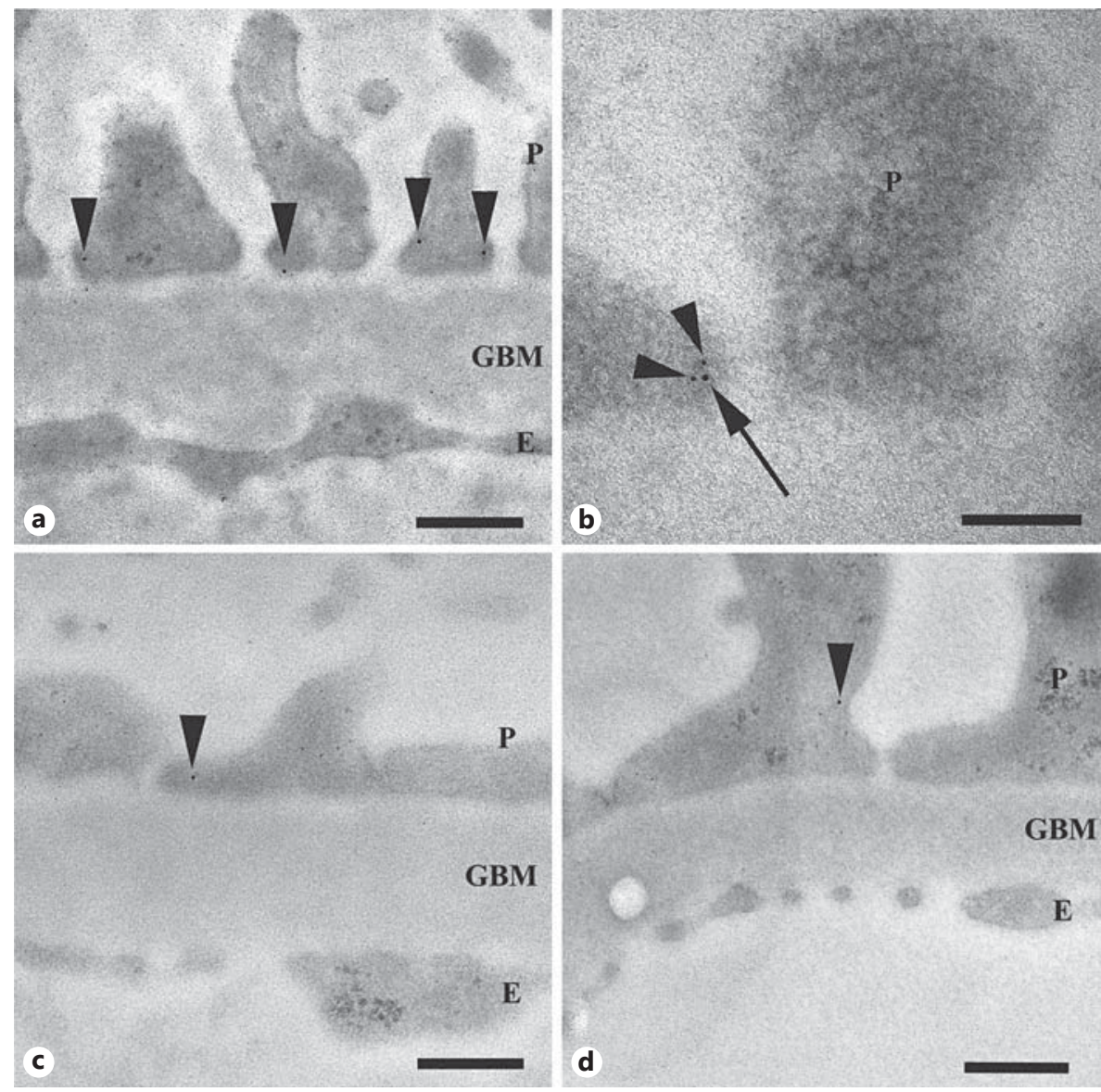

Fig. 1. iEM of human biopsies. Immunogold labeling of Neph1 (arrowheads) in kidney. a Neph1 in normal human kidney, localized to the foot processes close to the SD. b Double labeling of Neph1 (10 nm; arrow) and nephrin ( $5 \mathrm{~nm}$; arrowheads) in the foot process in normal human kidney. c, d Labeling of Neph1 in FSGS (c) and MCNS (d). P = Podocyte; E = endothelial cell. Scale bars = $300 \mathrm{~nm}(\mathbf{a}, \mathbf{c}, \mathbf{d})$ and $100 \mathrm{~nm}(\mathbf{b})$.

\section{Statistical Methods}

In comparisons between groups, a one-way ANOVA was used, followed by Dunnett's test comparing the means of the diseased group with the control group mean. For skewed distributed data, we used Kruskal-Wallis ANOVA by ranks. The Spearman rank-order correlation coefficient was used to measure the association between variables within each group. $\mathrm{p}<0.05$ was considered statistically significant. The software used was Statistica 9.0 (StatSoft Inc., Tulsa, Okla., USA).

\section{Results}

\section{Localization of Neph1 in Normal Kidney Material}

We localized Neph1 mainly to, and in close proximity to, the SD and to the podocyte cytoplasm (fig. 1a). Expression was also observed in the glomerular endothelium $(0.5 \pm 0.3 \mathrm{Au}$ / $\left.\mu \mathrm{m}^{2}\right)$ but only negligible amounts in the GBM $\left(0.1 \pm 0.0 \mathrm{Au} / \mu \mathrm{m}^{2}\right)$. There was no change in the amount of Neph1 in the endothelium of diseased tissue (data not shown) compared to that of 
Table 2. Expression of Neph1 in controls and biopsies based on $\mathrm{EEM}\left(\mathrm{Au} / \mu \mathrm{m}^{2}\right)$

\begin{tabular}{lllll}
\hline & Proteinuria, g/ 24 h & Podocytes & FPE areas & Non-FPE areas \\
\hline Controls $(\mathrm{n}=5)$ & 0 & $1.5 \pm 0.2$ & - & - \\
FSGS $(\mathrm{n}=5)$ & $1-8$ & $0.3 \pm 0.1^{*}$ & $0.3 \pm 0.2^{*}$ & $0.5 \pm 0.3^{*}$ \\
MCNS (n = 5) & $1-27$ & $0.5 \pm 0.1^{*}$ & $0.5 \pm 0.1^{*}$ & $0.5 \pm 0.2^{*}$ \\
\hline
\end{tabular}

Data are presented as means \pm standard deviation and are based on counting 3 images in 6 randomly selected capillaries, thus 18 images per glomerulus per biopsy. ${ }^{*} \mathrm{p}<0.05$ compared to controls.

Table 3. Expression of nephrin in controls and biopsies based on iEM $\left(\mathrm{Au} / \mu \mathrm{m}^{2}\right)$

\begin{tabular}{lllll}
\hline & Proteinuria, g/24h & Podocytes & FPE areas & Non-FPE areas \\
\hline Controls $(\mathrm{n}=4)$ & 0 & $2.4 \pm 0.6$ & - & - \\
FSGS $(\mathrm{n}=4)$ & $1-8$ & $2.0 \pm 0.4$ & $2.3 \pm 0.4$ & $1.4 \pm 0.0^{\mathrm{a}}$ \\
MCNS $(\mathrm{n}=5)$ & $1-27$ & $1.0 \pm 0.2^{*}$ & $0.9 \pm 0.2^{*}$ & $1.2 \pm 0.4^{*}$
\end{tabular}

Data are presented as means \pm standard deviation and are based on counting 3 images in 6 randomly selected capillaries, thus 18 images per glomerulus per biopsy. ${ }^{*} \mathrm{p}<0.05$ compared to controls. ${ }^{a}$ Only one observation.

Table 4. Expression of Neph1 in ADR mice based on iEM $\left(\mathrm{Au} / \mu \mathrm{m}^{2}\right)$

\begin{tabular}{lllll}
\hline & $\begin{array}{l}\text { Proteinuria, } \\
\mu \mathrm{BSA} / \mu \mathrm{l}\end{array}$ & Podocytes & FPE areas & Non-FPE areas \\
\hline Controls $(\mathrm{n}=4)$ & - & $2.7 \pm 0.3$ & - & - \\
ADR day 7 $(\mathrm{n}=4)$ & $>1$ to $>5$ & $1.1 \pm 0.2^{*}$ & $1.0 \pm 0.2^{*}$ & $1.2 \pm 0.1^{*}$ \\
ADR day $14(\mathrm{n}=4)$ & $>5$ & $0.8 \pm 0.1^{*}$ & $0.6 \pm 0.1^{*}$ & $0.9 \pm 0.1^{*}$ \\
\hline
\end{tabular}

Data are presented as means \pm standard deviation. Albuminuria measured on gel was graded as follows: $0=$ no visible indication; $1=$ trace of marker; $2=<0.5 \mu \mathrm{g} \mathrm{BSA} / \mu \mathrm{l} ; 3=>0.5$ to $<1 \mu \mathrm{g} \mathrm{BSA} / \mu \mathrm{l} ; 4=>1$ to $<5 \mu \mathrm{g}$ $\mathrm{BSA} / \mu \mathrm{l} ; 5=>5 \mu \mathrm{g} \mathrm{BSA} / \mu \mathrm{l} .{ }^{*} \mathrm{p}<0.05$ compared to controls.

controls. Double staining of Neph1 and nephrin in normal human kidney showed the proteins in close connection in the SD (fig. 1b).

\section{Semiquantification of Neph1 and Nephrin in Human Glomerular Disease}

All FSGS and MCNS cases showed partial FPE. The number of slits per micrometer GBM was $0.7 \pm 0.5$ in FSGS and $0.4 \pm 0.3$ in MCNS compared to controls $(1.8 \pm 0.4 ; p<0.05)$. The total amount of Neph1 in the podocytes was significantly reduced in FSGS $\left(0.3 \pm 0.1 \mathrm{Au} / \mu \mathrm{m}^{2}\right.$; fig. 1c) and in MCNS $\left(0.5 \pm 0.1 \mathrm{Au} / \mu \mathrm{m}^{2}\right.$; fig. $\left.1 \mathrm{~d}\right)$ both in areas with and those without FPE compared to controls $\left(1.5 \pm 0.2 \mathrm{Au} / \mu \mathrm{m}^{2}\right.$; table 2$)$. In line with our previous results [7], we also found a decreased amount of nephrin in MCNS $\left(1.0 \pm 0.2 \mathrm{Au} / \mu \mathrm{m}^{2}\right)$ compared to controls $(2.4$ $\left.\pm 0.6 \mathrm{Au} / \mu \mathrm{m}^{2}\right)$, but no change in FSGS $\left(2.0 \pm 0.4 \mathrm{Au} / \mu \mathrm{m}^{2}\right.$; table 3$)$. 


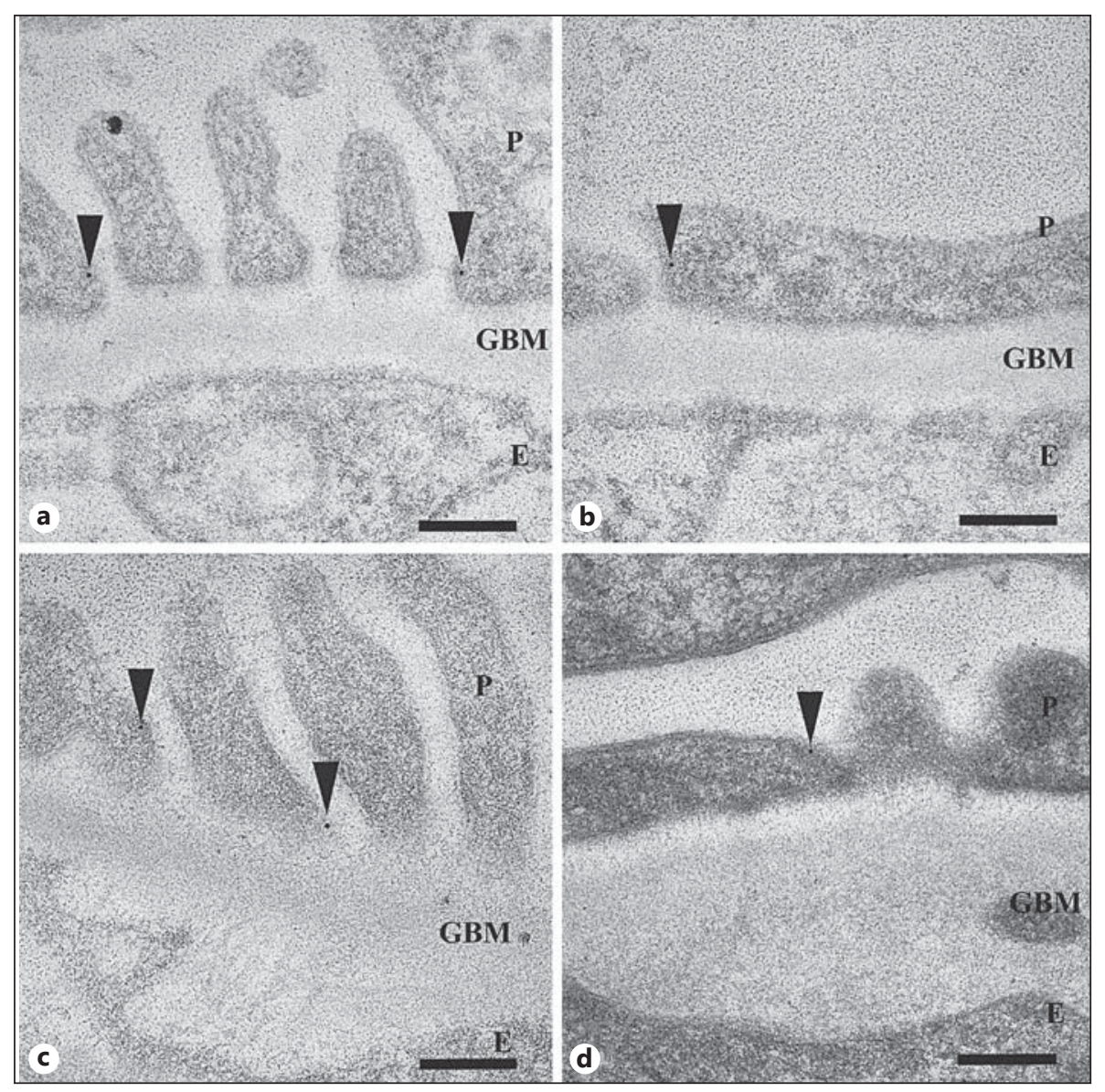

Fig. 2. iEM of mouse (a, b) and rat (c, d) biopsies. Immunogold labeling of Neph1 (arrowheads) in kidney. a Neph1 in normal mouse kidney, localized to the foot processes close to the SD. b Neph1 is reduced in ADR on day 14 both in areas with and those without FPE. c Neph1 in normal rat kidney, localized mainly to the SD. d Neph 1 is reduced in PAN on day 4 both in areas with and those without FPE. P = Podocyte; $\mathrm{E}=$ endothelial cell. Scale bars $=200 \mathrm{~nm}$.

\section{Semiquantification of Neph1 in ADR Mice}

The albuminuria grade was 5 on SDS gel (table 4) for all mice included in the day 7 group. All cases showed partial FPE. The number of slits per micrometer GBM was $1.6 \pm 0.8$ compared to $3.0 \pm 0.8$ in controls $(\mathrm{p}<0.05)$. In the day 14 group, the albuminuria grade ranged from 4 to 5 , and sclerotic lesions were detected in all but one mouse. All cases showed partial FPE. The number of slits per micrometer GBM was $1.4 \pm 0.5$.

Neph1 was significantly reduced in total amount $\left(1.1 \pm 0.2\right.$ and $\left.0.8 \pm 0.1 \mathrm{Au} / \mu \mathrm{m}^{2}\right)$ both in areas with $\left(1.0 \pm 0.2\right.$ and $\left.0.6 \pm 0.1 \mathrm{Au} / \mu \mathrm{m}^{2}\right)$ and those without FPE $(1.2 \pm 0.1$ and $0.9 \pm 0.1 \mathrm{Au} /$ $\mu \mathrm{m}^{2}$ ) in the ADR day 7 and day 14 groups (fig. 2b), respectively, compared to controls (2.7 \pm $0.3 \mathrm{Au} / \mu^{2}$; fig. $2 \mathrm{a}$; table 4). Nephrin was unchanged on day 7 but slightly reduced on day 14 (table 5).

\section{Neph1 and Nephrin Expression in PAN Rats}

The total amount of Neph1 in the podocytes was significantly reduced in the PAN day 2 group $\left(0.4 \pm 0.1 \mathrm{Au} / \mu \mathrm{m}^{2}\right)$ both in areas with $\left(0.4 \pm 0.1 \mathrm{Au} / \mu \mathrm{m}^{2}\right)$ and those without FPE $(0.3$ $\left.\pm 0.0 \mathrm{Au} / \mu \mathrm{m}^{2}\right)$. Further reductions were seen in the day 4 group $\left(0.2 \pm 0.1 \mathrm{Au} / \mu \mathrm{m}^{2}\right)$, both in 
Table 5. Expression of nephrin in ADR mice based on $\mathrm{iEM}\left(\mathrm{Au} / \mu \mathrm{m}^{2}\right)$

\begin{tabular}{lllll}
\hline & $\begin{array}{l}\text { Proteinuria, } \\
\mu \text { BSA } / \mu \mathrm{l}\end{array}$ & Podocytes & FPE areas & Non-FPE areas \\
\hline Controls $(\mathrm{n}=4)$ & - & $1.5 \pm 0.3$ & - & - \\
ADR day 7 $(\mathrm{n}=4)$ & $>1$ to $>5$ & $1.3 \pm 0.2$ & $1.4 \pm 0.8$ & $1.6 \pm 0.3$ \\
ADR day 14 $(\mathrm{n}=4)$ & $>5$ & $0.8 \pm 0.2^{*}$ & $0.6 \pm 0.1$ & $0.9 \pm 0.3$ \\
\hline
\end{tabular}

Data are presented as means \pm standard deviation. Albuminuria grades: see table $4 .{ }^{*} \mathrm{p}<0.05$ compared to controls.

Table 6. Expression of Neph1 in PAN rats based on $\mathrm{iEM}\left(\mathrm{Au} / \mu \mathrm{m}^{2}\right)$

\begin{tabular}{lllll}
\hline & $\begin{array}{l}\text { Proteinuria, } \\
\mathrm{mg} / \mathrm{mmol}\end{array}$ & Podocytes & FPE areas & Non-FPE areas \\
\hline Controls $(\mathrm{n}=4)$ & $100-107$ & $0.7 \pm<0.1$ & - & - \\
PAN day 2 $(\mathrm{n}=3)$ & 118 & $0.4 \pm 0.1^{*}$ & $0.4 \pm 0.1$ & $0.3 \pm<0.1^{*}$ \\
PAN day 4 $(\mathrm{n}=4)$ & 2,353 & $0.2 \pm 0.1^{*}$ & $0.1 \pm 0.1^{*}$ & $0.1 \pm 0.1^{*}$ \\
\hline
\end{tabular}

Data are presented as means \pm standard deviation. ${ }^{*} \mathrm{p}<0.05$ compared to controls.

Table 7. Summary of findings based on iEM

\begin{tabular}{lll}
\hline & Neph1 & Nephrin \\
\hline FSGS & $\downarrow$ & $\rightarrow$ \\
FPE areas & $\downarrow$ & $\rightarrow$ \\
non-FPE areas & $\downarrow$ & $\rightarrow$ \\
\hline MCNS & $\downarrow$ & $\downarrow$ \\
FPE areas & $\downarrow$ & $\downarrow$ \\
non-FPE areas & $\downarrow$ & $\downarrow$ \\
\hline ADR, day 7 & $\downarrow$ & $\rightarrow$ \\
FPE areas & $\downarrow$ & $\rightarrow$ \\
non-FPE areas & $\downarrow$ & $\rightarrow$ \\
ADR, day 14 & $\downarrow$ & $\downarrow$ \\
FPE areas & $\downarrow$ & $\rightarrow$ \\
non-FPE areas & $\downarrow$ & $\rightarrow$ \\
\hline PAN, day 2 & $\downarrow$ & $\downarrow^{\text {a }}$ \\
FPE areas & $\rightarrow$ & $\downarrow^{\text {a }}$ \\
non-FPE areas & $\downarrow$ & $\downarrow^{\text {a }}$ \\
PAN, day 4 & $\downarrow$ & $\downarrow^{\text {a }}$ \\
FPE areas & $\downarrow$ & $\downarrow^{\text {a }}$ \\
non-FPE areas & $\downarrow$ & $\downarrow^{\text {a }}$ \\
\hline controls. ${ }^{\text {a Previously published }[7] .}$ & \\
\hline
\end{tabular}

areas with FPE $\left(0.1 \pm 0.1 \mathrm{Au} / \mu \mathrm{m}^{2}\right.$; fig. $\left.2 \mathrm{~d}\right)$ and those without $\left(0.1 \pm 0.1 \mathrm{Au} / \mu \mathrm{m}^{2}\right)$ compared to controls $\left(0.7 \pm 0.0 \mathrm{Au} / \mu^{2}\right.$; fig. 2 c; table 6$)$. Nephrin was reduced in a similar pattern, both on day 2 and day 4, as previously published [17].

All results are summarized in table 7. 


\section{Discussion}

Proteins localized to and associated with the SD have important functions both in controlling the podocyte structure and as part of signaling pathways. Recent studies have identified Neph1 as a key player in connecting the SD to the foot process cytoskeleton. Together with its binding partner nephrin, the protein may play a key role in maintaining the structure of the filtration barrier [20]. Neph1 and nephrin form a complex with podocin that functions as a transmembrane receptor.

Various actin-associated and adaptor proteins bind to the complex, for example, CD2AP, ZO-1 [21], $\alpha$-actinin 4, and TRPC6, which thereby holds a critical role in signal transduction to the actin cytoskeleton in podocytes [22-24]. Disturbances in these pathways may lead to disorganization of the cytoskeleton, resulting in FPE.

With immunoelectron microscopy (iEM), we localized Neph1 mainly to, and in close proximity to, the SD as well as to the podocyte cytoplasm. Double staining of Neph1 and nephrin in normal human kidney showed the proteins in close connection in the SD, which has not been shown in human material by iEM before.

By semiquantification in biopsies from patients with perihilar FSGS and MCNS, we found a significant reduction in the total amount of Neph1 in the podocyte foot processes. The expression was reduced in areas with and without FPE. Nephrin was also reduced in MCNS but unchanged in FSGS in areas with and without FPE. This may indicate a dissociation of the Neph1-nephrin complex in FSGS.

Liu et al. [24] found that a disruption of the Neph1-nephrin complex resulted in proteinuria with intact foot processes. It has been noted that Neph1 disassociates from its interaction partners ZO-1 and nephrin and translocates from the cell membrane to the cytoplasm in response to glomerular injury in animal and cell culture models [12, 25]. In our material, we could not, however, see a distinct change in the localization of Neph1 in either FSGS or MCNS compared to controls.

Otaki et al. [12] detected a discontinuous immunofluorescence pattern of Neph1 in early ADR along with dissociation from nephrin when neither proteinuria nor any morphological alterations were detected. They concluded that the dissociation is a critical event in the initiation phase of ADR. We could also see a significant reduction of Neph1 on day 7 in ADR mice in combination with an unchanged amount of nephrin. These data also mirror our findings in the human FSGS material. By day 14, we saw an even further reduction of Neph1 and a slight reduction in the amount of nephrin in areas with FPE.

In the MCNS experimental model of PAN, Neph1 was reduced in the material from days 2 and 4 in areas with and without FPE. This is the same pattern as for nephrin, as previously published [17].

With one of the components of the Neph1-nephrin complex lost or damaged, the binding adaptor proteins, and thereby the cytoskeleton, are also affected, and it is reasonable to suspect FPE and proteinuria to be a direct result. This could either be due to glomerular injury affecting the interactions and distribution of the proteins or because of specific mutations of the genes, though this is unlikely in these acquired diseases.

With nephrin (but not Neph1) unchanged in FSGS and early ADR, this could indicate a role for Neph1 in the pathogenesis. A decrease in Neph1 could lead to a dysfunctional SD complex with defect signaling pathways, ultimately affecting the actin cytoskeleton and leading to FPE. Certainly, other factors and components could be of great importance and behind glomerular diseases characterized by proteinuria and FPE, but Neph1 is clearly well worth further investigation. 


\section{References}

1 Shankland SJ: The podocyte's response to injury: role in proteinuria and glomerulosclerosis. Kidney Int 2006; 69:2131-2147.

-2 Smoyer WE, Mundel P: Regulation of podocyte structure during the development of nephrotic syndrome. J Mol Med 1998;76:172-183.

-3 Kestilä M, Lenkkeri U, Männikkö M, Lamerdin J, McCready P, Putaala H, Ruotsalainen V, Morita T, Nissinen M, Herva R, Kashtan CE, Peltonen L, Holmberg C, Olsen A, Tryggvason K: Positionally cloned gene for a novel glomerular protein nephrin is mutated in congenital nephritic syndrome. Mol Cell 1998;1:574-582.

-4 Donoviel DB, Freed DD, Vogel H, Potter DG, Hawkins E, Barrish JP, Mathur BN, Turner CA, Geske R, Montgomery CA, Starbuck M, Brandt M, Gupta A, Ramirez-Solis R, Zambrowicz BP, Powell DR: Proteinuria and perinatal lethality in mice lacking NEPH1, a novel protein with homology to NEPHRIN. Mol Cell Biol 2001;21: 4829-4836.

5 George B, Verma R, Soofi AA, Garg P, Zhang J, Park TJ, Giardino L, Ryzhova L, Johnstone DB, Wong H, Nihalani D, Salant DJ, Hanks SK, Curran T, Rastaldi MP, Holzman LB: Crk1/2-dependent signaling is necessary for podocyte foot process spreading in mouse models of glomerular disease. J Clin Invest 2012;1;122:674-692.

-6 Tryggvason K, Patrakka J, Wartiovaara J: Hereditary proteinuria syndromes and mechanisms of proteinuria. N Engl J Med 2006;354:1387-1401.

7 Wernerson A, Dunér F, Pettersson E, Widholm SM, Berg U, Ruotsalainen V, Tryggvason K, Hultenby K, Söderberg M: Altered ultrastructural distribution of nephrin in minimal change nephrotic syndrome. Nephrol Dial Transplant 2003;18:70-76.

-8 Barletta GM, Kovari IA, Verma RK, Kerjaschki D, Holzman LB: Nephrin and Neph1 co-localize at the podocyte foot process intercellular junction and form cis hetero-oligomers. J Biol Chem 2003;23;278:19266-19271.

-9 Gerke P, Huber TB, Sellin L, Benzing T, Walz G: Homodimerization and heterodimerization of the glomerular podocyte proteins nephrin and NEPH1. J Am Soc Nephrol 2003;14:918-926.

10 Garg P, Verma R, Nihalani D, Johnstone DB, Holzman LB: Neph1 cooperates with nephrin to transduce a signal that induces actin polymerization. Mol Cell Biol 2007;27:8698-8712.

-11 Neumann-Haefelin E, Kramer-Zucker A, Slanchev K, Hartleben B, Noutsou F, Martin K, Wanner N, Ritter A, Gödel M, Pagel P, Fu X, Müller A, Baumeister R, Walz G, Huber TB: A model organism approach: defining the role of Neph proteins as regulators of neuron and kidney morphogenesis. Hum Mol Genet 2010;19:2347-2359.

-12 Otaki Y, Miyauchi N, Higa M, Takada A, Kuroda T, Gejyo F, Shimizu F, Kawachi H: Dissociation of NEPH1 from nephrin is involved in development of a rat model of focal segmental glomerulosclerosis. Am J Physiol Renal Physiol 2008;295:F1376-F1387.

13 Perisic L, Lal M, Hulkko J, Hultenby K, Önfelt B, Sun Y, Dunér F, Patrakka J, Betsholtz C, Uhlen M, Brismar H, Tryggvason K, Wernerson A, Pikkarainen T: Plekhh2, a novel podocyte protein downregulated in human focal segmental glomerulosclerosis, is involved in matrix adhesion and actin dynamics. Kidney Int 2012;82:10711083.

14 Ruotsalainen V, Reponen P, Khoshnoodi J, Kilpeläinen P, Tryggvason K: Monoclonal antibodies to human nephrin. Hybrid Hybridomics 2004;23:55-63.

-15 D’Agati VD, Fogo AB, Bruijn JA, Jennette JC: Pathologic classification of focal segmental glomerulosclerosis: a working proposal. Am J Kidney Dis 2004;43:368-382.

16 D’Agati VD, Kaskel FJ, Falk RJ: Focal segmental glomerulosclerosis. N Engl J Med 2011;365:2398-2411.

-17 Dunér F, Lindström K, Hultenby K, Hulkko J, Patrakka J, Tryggvason K, Haraldsson B, Wernerson A, Pettersson E: Permeability, ultrastructural changes, and distribution of novel proteins in the glomerular barrier in early puromycin aminonucleoside nephrosis. Nephron Exp Nephrol 2010;116:e42-e52.

18 Wang Y, Wang YP, Tay YC, Harris DC: Progressive Adriamycin nephropathy in mice: sequence of histologic and immunohistochemical events. Kidney Int 2000;58:1797-1804.

19 Weibel E: Stereological Methods: Practical Methods for Biological Morphometry. London, Academic, 1979, vol 1.

20 Hartleben B, Schweizer H, Lübben P, Bartram MP, Möller CC, Herr R, Wei C, Neumann-Haefelin E, Schermer B, Zentgraf H, Kerjaschki D, Reiser J, Walz G, Benzing T, Huber TB: Neph-nephrin proteins bind the Par3-Par6atypical protein kinase C (aPKC) complex to regulate podocyte cell polarity. J Biol Chem 2008;283:2303323038.

21 Huber TB, Schmidts M, Gerke P, Schermer B, Zahn A, Hartleben B, Sellin L, Walz G, Benzing T: The carboxyl terminus of Neph family members binds to the PDZ domain protein zonula occludens-1. J Biol Chem 2003; 278:13417-13421.

22 Patrakka J, Tryggvason K: Nephrin: a unique structural and signaling protein of the kidney filter. Trends Mol Med 2007;13:396-403.

-23 Pätäri-Sampo A, Ihalmo P, Holthöfer H: Molecular basis of the glomerular filtration: nephrin and the emerging protein complex at the podocyte slit diaphragm. Ann Med 2006;38:483-492.

24 Liu G, Kaw B, Kurfis J, Rahmanuddin S, Kanwar YS, Chugh SS: Neph1 and nephrin interaction in the slit diaphragm is an important determinant of glomerular permeability. J Clin Invest 2003;112:209-221.

25 Wagner MC, Rhodes G, Wang E, Pruthi V, Arif E, Saleem MA, Wean SE, Garg P, Verma R, Holzman LB, Gattone V, Molitoris BA, Nihalani D: Ischemic injury to kidney induces glomerular podocyte effacement and dissociation of slit diaphragm proteins Neph1 and ZO-1. J Biol Chem 2008;283:35579-35589. 